\title{
SPECTROPHOTOMETRIC EVALUATION OF FLAVONOIDS, PHENOLCARBOXYLIC ACIDS AND TOTAL PHENOLIC CONTENTS OF SEVERAL INDIGENOUS HERBAL PRODUCTS WITH POTENTIAL HEPATOPROTECTIVE EFFECT
}

\author{
LILIANA COSTEA *, MANUELA GHICA *, TEODORA COSTEA*, CERASELA ELENA GÎRD \\ "Carol Davila" University of Medicine and Pharmacy, Faculty of Pharmacy, 6 Traian Vuia Street, 020956, Bucharest, \\ Romania
}

*corresponding author: manuela.ghica@umfcd.ro

\#Authors with equal contribution.

Manuscript received: May 2021

\begin{abstract}
Chronic liver diseases (CLD) are leading causes of morbidity worldwide. Current evidence highlights the beneficial properties associated to polyphenols in CLD, due to their antioxidant activity. Therefore, the aim of our study was the evaluation of phenolic content of several indigenous herbal products (agrimony, cichory and dandelion aerial parts; artichoke and rosemary leaves), in view of obtaining a phytomedicine with hepatoprotective effect. Flavonoids, phenolcarboxylic acids and total phenolic contents were assessed by means of spectrophotometric methods using different solvents (70\% ethanol, $50 \%$ ethanol, $20 \%$ ethanol and water). Agrimony aerial parts and rosemary leaves showed the highest flavonoids $(1.17 \mathrm{~g}$ rutin/100 g dried herbal product and $1.27 \mathrm{~g}$ rutin/100 $\mathrm{g}$ dried herbal product) and phenolcarboxylic acids contents $(6.55 \mathrm{~g}$ chlorogenic acid/100 $\mathrm{g}$ dried herbal product and $5.67 \mathrm{~g}$ chlorogenic acid/100 g dried herbal product). Moreover, according to our results, $50 \%$ ethanol provided the optimal extraction of phenolic compounds for all analysed herbal products, except for dandelion aerial parts, for which $20 \%$ ethanol was the best extraction solvent. Analysed herbal products are a source of phenolic compounds. Nevertheless, the solvent is a key factor that greatly influences the phenolic content.
\end{abstract}

\section{Rezumat}

Afecțiunile hepatice de natură cronică reprezintă o cauză majoră de deces la nivel mondial. Cercetări recente au evidențiat rolul benefic al polifenolilor în tratamentul acestor afecțiuni, datorită activității lor antioxidante. Scopul lucrării a constat în evaluarea conținutului de polifenoli a unor materii prime vegetale (părți aeriene de cicoare, păpădie, turiță mare, frunze de anghinare, de rozmarin), în vederea obținerii unui fitopreparat asociat în tratamentul hepatopatiilor. Pentru evaluarea conținutului de polifenoli totali, acizi fenolcarboxilici și flavone s-au utilizat metode spectrofotometrice. Determinările au fost realizate utilizând solvenți diferiți (etanol 70\%, etanol 50\%, etanol 20\% și apă). Părțile aeriene de turiță mare și frunzele de rozmarin au avut cel mai mare conținut de flavone $(1,17 \mathrm{~g}$ rutozidă/100 g produs vegetal uscat și $1,27 \mathrm{~g}$ rutozidă/100 g produs vegetal uscat) și de acizi fenolcarboxilici (6,55 g acid clorogenic/100 g produs vegetal uscat și 5,67\% g acid clorogenic/100 $\mathrm{g}$ produs vegetal uscat). Cea mai mare cantitate de principii active s-a obținut utilizând ca solvent de extracție etanolul de concentrație 50\% (cu excepția părților aeriene de păpadie pentru care etanolul de concentrație $20 \%$ a condus la cea mai mare cantitate de principii active). Produsele analizate reprezintă o sursă importantă de polifenoli. Totuși, solventul reprezintă un factor cheie care influențează în mod semnificativ extracția principiilor active de interes.

Keywords: agrimony, total phenolic content, liver diseases, oxidative stress

\section{Introduction}

Chronic liver diseases (CLD) such as non-alcoholic fatty liver disease, hepatitis, cirrhosis or hepatocellular carcinoma are leading causes of morbidity worldwide $[13,17]$. The main aetiologies of liver diseases are alcohol abuse, hepatitis virus infections and metabolic syndrome. The most important pathological processes of liver diseases are inflammation, immune response disruption, alteration of gut-microbiota axis, alteration of gut-liver axis and oxidative stress [5, 8, 13, 17, 21,31]. It is well known that oxidative stress represents a hallmark of liver injury $[5,8,13,15,31]$, since it is involved in: (i) inflammation and apoptosis [17], (ii) alteration of the mitochondrial membrane permeability and transition potential which initiates the release of pro-apoptotic factors [17], (iii) alteration of lipids, proteins and DNA contents, which further leads to steatosis/fibrosis [17]. Moreover oxidative stress is involved in modulation of several pathways that regulate gene transcription, protein expression and the immune response [5, 17].

Current evidence highlights the beneficial properties associated to polyphenols for chronic liver diseases treatment [2, 3, 22, 27]. Several mechanisms are involved in the hepatoprotective effect of polyphenols: 
(i) scavenger activity of free radicals; (ii) inhibiting the formation and expression of inflammatory cytokine $[17,25]$; (iii) regulation of gene-expression or signalling pathways - up-regulation of Bcl-2 (B-cell lymphoma 2) apoptotic pathway, activation of NRf2 - nuclear factor erythroid 2-related factor 2 mediated pathway, suppressing of canonical $\mathrm{Nf}-\mathrm{kB}$ and PI3K/AKT (phosphatidylinositol-3-kinase/protein kinase B) signalling pathways etc.; (iv) inhibition of cyclooxygenase and iNOS (nitric oxide synthase); (v) downregulation of lipogenic genes (fatty acid synthase, acetyl-CoA carboxylase); (vi) up-regulation of PPAR $\alpha$ (peroxisome proliferator- activated) receptors and (vii) reduced serum fibrosis markers [11, 17, 25]. Considering the scientific data, the aim of our paper was the evaluation of phenolic content of several indigenous herbal products - agrimony aerial parts (Agrimoniae herba), common cichory aerial parts (Cichorii herba), rosemary leaves (Rosmarinifolium), dandelion aerial parts (Taraxaci herba) and artichoke leaves (Cynarae folium), in view of obtaining a phytomedicine with hepatoprotective effect. Indigenous herbal products were selected based on their chemical composition, rich in phenolic compounds [7, 9, 10, 12, 14].

\section{Materials and Methods}

\section{Plant Material}

Herbal products (agrimony aerial parts - encoded A, common cichory aerial parts - encoded $\mathrm{CH}$, dandelion aerial parts - encoded T, artichoke leaves - encoded $\mathrm{CY}$ and rosemary leaves - encoded R) were acquired in 2019 (as medicinal tea), from indigenous manufacturers. Reagents and solvents

All chemicals (aluminium chloride, chlorogenic acid, ethanol, hydrochloric acid, rutin, sodium hydroxide, sodium nitrite, tannic acid, sodium carbonate) were purchased from Sigma-Aldrich (Germany).

Obtaining the extractive solutions. For evaluation of the total phenolic, flavonoids and phenolcarboxylic acids contents, $1 \mathrm{~g}$ of each herbal product was heated twice with $25 \mathrm{~mL}$ solvent (70\% alcohol, 50\% alcohol, $20 \%$ alcohol and water) on a heated condenser for 30 min. After cooling, the solutions were filtered in a 50 $\mathrm{mL}$ volumetric flask and filled to mark with the same solvent. Analysed solutions were encoded as follows (Table I).

\begin{tabular}{lcccc}
\multirow{2}{*}{\multicolumn{1}{c}{ Herbal product }} & \multicolumn{4}{c}{ Solvent } \\
\cline { 2 - 5 } & $70 \%$ ethanol & $50 \%$ ethanol & $20 \%$ ethanol & water \\
\hline Agrimony aerial parts & SA70 & SA50 & SA20 & SAA \\
\hline Common cichory aerial parts & SCH70 & SCH50 & SCH20 & SCHA \\
\hline Artichoke leaves & SCY70 & SCY50 & SCY20 & SCYA \\
\hline Rosemary leaves & SR70 & SR50 & SR20 & SRA \\
\hline Dandelion aerial parts & ST70 & ST50 & ST20 & STA
\end{tabular}

These analyses were necessary, thereby to choose the solvent, that provides the best extraction yield of active substances. The optimum solvent will be further used for obtaining freeze-dried extracts, rich in phenolic compounds.

Methods

Spectrophotometric assays. Total phenolic content (TPC) was determined with the Folin-Ciocâlteu reagent as previously described $[14,19,30]$. Results were expressed as g tannic acid/100 g dried herbal product, based on a calibration curve $\left(2.04-9.18 \mu \mathrm{g} / \mathrm{mL}, \mathrm{R}^{2}=\right.$ $0.9994, \mathrm{n}=8)$. The flavonoids content $(\mathrm{FL})$ was determined based on the chelating reaction with aluminium chloride and results were expressed as $g$ rutin $/ 100 \mathrm{~g}$ dried herbal product using the following calibration curve $\left(5.0\right.$ - $35.0 \mu \mathrm{g} / \mathrm{mL}, \mathrm{R}^{2}=0.9998$, $\mathrm{n}=11$ ) $[14,19]$. Phenolcarboxylic acids (PCAs) were evaluated based on formation of oxymes in the presence of sodium nitrite/hydrochloric acid and sodium hydroxide. Results were expressed as g chlorogenic acid/100 g dried herbal product (chlorogenic acid calibration curve - 11.3-52.7 $\mu \mathrm{g} / \mathrm{mL}, \mathrm{R}^{2}=0.9998, \mathrm{n}=6$ ) $[14,19]$. For all spectrophotometric assays, a Jasco V-530 spectrophotometer (Jasco, Japan) was used.

\section{Statistical analysis}

For each herbal product, three samples were analysed and all assays were carried out in triplicate $(n=3)$. The results were expressed as mean \pm SD (standard deviation). Standard deviation was determined using Microsoft Office programme (Excell, 2010). Statistical analysis was performed using the open source software R [24]. Since the samples related to our study were too small for a classical approach, we elaborated robust measures for mean and standard deviation and we applied a robust ANOVA version for comparing our datasets [20]. We used a similar parametric framework, but with a bootstrap approach, without worrying about basic violation of normality, homoscedasticity and sphericity [4]. Statistical significance was accepted for alpha-level 0.05 and post hoc analysis for a Bonferroni adjusted alpha level. The factors that affected the continuous variable concentration were a focal variable denoted with Type (with five levels: Agrimoniae herba, Cichorii herba, Cynarae folium, Rosmarini folium and Taraxaci herba) and other two moderator variables: the solvent (with four levels: ethanol $20 \%$, ethanol $50 \%$, ethanol $70 \%$ and water) and the active substance (with three levels: PCAs, FL and TPC). We computed 
a three-way robust ANOVA to evaluate how each independent factor (herbal product, solvent and active substance) interact with a continuous variable denoted by concentration. There was a statistically significant three-way interaction between the herbal product, the solvent and the active substance $(\mathrm{p}=0.001)$ and a

simple two-way post hoc interaction for all pairwise of factors implied $(\mathrm{p}=0.001)$.

\section{Results and Discussion}

The results for our spectrophotometric assays are presented in Table II.

Table II

Spectrophotometric results for analysed herbal products

FL (g rutin/100 g dried herbal product)

$$
\begin{array}{llll}
\text { SA70 } & \text { SA50 } & \text { SA20 } & \text { SAA }
\end{array}
$$

$\begin{array}{cccc}1.1745 \pm 0.0293 & 1.0332 \pm 0.0836 & 0.9447 \pm 0.1368 & 0.6453 \pm 0.0496 \\ \text { SCH70 } & \text { SCH50 } & \text { SCH20 } & \text { SCHA }\end{array}$

$\begin{array}{cccc}0.4771 \pm 0.0348 & 0.5596 \pm 0.0482 & 0.4350 \pm 0.0116 & 0.3814 \pm 0.0312\end{array}$

$\begin{array}{llll}\text { SCY70 } & \text { SCY50 } & \text { SCY20 } & \text { SCYA }\end{array}$

$0.7382 \pm 0.0590 \quad 0.7497 \pm 0.0244 \quad 0.4361 \pm 0.0476 \quad 0.4121 \pm 0.0277$

$$
\begin{array}{cccr}
\text { SR70 } & \text { SR50 } & \text { SR20 } & \text { SRA }
\end{array}
$$

$1.0271 \pm 0.1130 \quad 1.2771 \pm 0.0684 \quad 0.7991 \pm 0.1469 \quad 0.1156 \pm 0.0099$

$\begin{array}{llll}\text { ST70 } & \text { ST50 } & \text { ST20 } & \text { STA }\end{array}$

$0.6737 \pm 0.0192 \quad 0.6497 \pm 0.1479 \quad 0.9154 \pm 0.1138 \quad 0.7808 \pm 0.1655$

PCAs (g chlorogenic acid/100 g dried herbal product)

$$
\begin{array}{llll}
\text { SA70 } & \text { SA50 } & \text { SA20 } & \text { SAA }
\end{array}
$$

$\begin{array}{cccc}4.1655 \pm 0.2108 & 4.7469 \pm 0.1683 & 6.5580 \pm 0.4671 & 3.1842 \pm 0.1978 \\ \text { SCH70 } & \text { SCH50 } & \text { SCH } 20 & \text { SCHA }\end{array}$

$1.8201 \pm 0.0503 \quad 1.4614 \pm 0.0766 \quad 1.4840 \pm 0.0273 \quad 1.4974 \pm 0.1054$

$\begin{array}{llll}\text { SCY70 } & \text { SCY50 } & \text { SCY20 } & \text { SCYA }\end{array}$

$\begin{array}{llll}0.6572 \pm 0.1201 & 0.5643 \pm 0.0401 & 0.6170 \pm 0.0697 & 0.3802 \pm 0.0428\end{array}$

$\begin{array}{llll}\text { SR70 } & \text { SR50 } & \text { SR20 } & \text { SRA }\end{array}$

$\begin{array}{cccc}5.6123 \pm 0.2365 & 5.6733 \pm 0.7740 & 4.9732 \pm 0.4402 & 0.8151 \pm 0.0582 \\ \text { ST70 } & \text { ST50 } & \text { ST20 } & \text { STA }\end{array}$

$2.0383 \pm 0.1333 \quad 2.1674 \pm 0.1824 \quad 2.6529 \pm 0.0438 \quad 2.8350 \pm 0.0867$

TPC ( $\mathrm{g}$ tannic acid/100 $\mathrm{g}$ dried herbal product)

$\begin{array}{llll}\text { SA70 } & \text { SA50 } & \text { SA20 } & \text { SAA }\end{array}$

$8.0232 \pm 1.9744 \quad 8.5634 \pm 0.2243 \quad 8.2553 \pm 1.1594 \quad 4.5732 \pm 0.5401$

$\begin{array}{llll}\mathrm{SCH} 70 & \mathrm{SCH} 50 & \mathrm{SCH} 20 & \text { SCHA }\end{array}$

$2.0884 \pm 0.3213 \quad 2.1534 \pm 0.0303 \quad 1.9186 \pm 0.0769 \quad 1.6393 \pm 0.0746$

$\begin{array}{llll}\text { SCY70 SCY50 } & \text { SCY20 } & \text { SCYA }\end{array}$

$1.4222 \pm 0.1590 \quad 1.1984 \pm 0.2579 \quad 1.1228 \pm 0.1149 \quad 0.8756 \pm 0.0125$

$\begin{array}{llll}\text { SR70 } & \text { SR50 } & \text { SR20 } & \text { SRA }\end{array}$

$8.8233 \pm 1.1743 \quad 8.1027 \pm 0.6782 \quad 5.1887 \pm 0.1836 \quad 0.8604 \pm 0.0592$

$\begin{array}{llll}\text { ST70 } & \text { ST50 } & \text { ST20 } & \text { STA }\end{array}$

$2.8415 \pm 0.2213 \quad 2.9509 \pm 0.0486 \quad 3.3647 \pm 0.3786 \quad 3.0034 \pm 0.1058$

Legend: FL - flavonoids, PCAs - phenolcarboxylic acids, TPC - total phenolic content, SA - agrimony aerial parts extractive solutions (SA70 - using 70\% ethanol, SA50 - using 50\% ethanol, SA20 - using 20\% ethanol, SAA - using water); SCH - cichory aerial parts extractive solutions (SCH70 - using 70\% ethanol, SCH50 - using 50\% ethanol, SCH20 - using 20\% ethanol, SCHA - using water), SCY - artichoke leaves extractive solutions (SCY70 - using 70\% ethanol, SCY50 - using 50\% ethanol, SCY20 - using 20\% ethanol, SCYA - using water); SR - rosemary leaves extractive solutions (SR70 - using 70\% ethanol, SR50 - using 50\% ethanol, SR20 - using 20\% ethanol, SRA - using water); ST - dandelion aerial parts extractive solutions (ST70 - using 70\% ethanol, ST50 - using 50\% ethanol, ST20\% - using 20\% ethanol, STA - using water).

According to our results (Table II), all analysed herbal products are a source of flavonoids and phenolcarboxylic acids. Agrimony aerial parts and rosemary leaves showed the highest flavonoids ( $1.17 \mathrm{~g}$ rutin/100 $\mathrm{g}$ dried herbal product and $1.27 \mathrm{~g}$ rutin/100 $\mathrm{g}$ dried herbal product) and phenolcarboxylic acids contents (6.55 g chlorogenic acid/100 g dried herbal product and $5.67 \mathrm{~g}$ cholorogenic acid/100 g dried herbal product). According to previous published papers, agrimony aerial parts are a rich source of flavonoids and hydroxycinnamic acids [29]. Our results regarding the flavonoids content of Agrimoniae herba are much lower compared to Ciobanu $\mathrm{N}$ et al. [9] that found $3.72 \mathrm{~g}$ flavones (expressed as rutin equivalents)/100 $\mathrm{g}$ dried herbal product, using 70\% ethanol as extraction solvent [9]. For Agrimoniae herba, there were no statistically significant mean differences between all solvents in case of flavonoids, however regarding the total phenolic content, water showed a different behaviour. Still, there was a statistically significant simple main effect of all active substances for agrimony aerial parts ( $\mathrm{p}$ 0.001) (Figure 1a).

According to the scientific literature, cichory aerial parts are also an important source of phenolcarboxylic acids and flavonoids $[1,12]$. Regarding cichory aerial parts total phenolic content, it was difficult to compare 
our results with other reports, that found $14-23 \mathrm{~g}$ polyphenols/100 $\mathrm{g}$ dried herbal product (expressed as tannic acid equivalents), since these results were obtained using a 70\% hydroalcoholic dry extract [12]. Still, our results are much lower compared to Sahan $\mathrm{Y}$ et al. that found $3.3-8.8 \mathrm{~g}$ polyphenols $/ 100 \mathrm{~g}$ dried

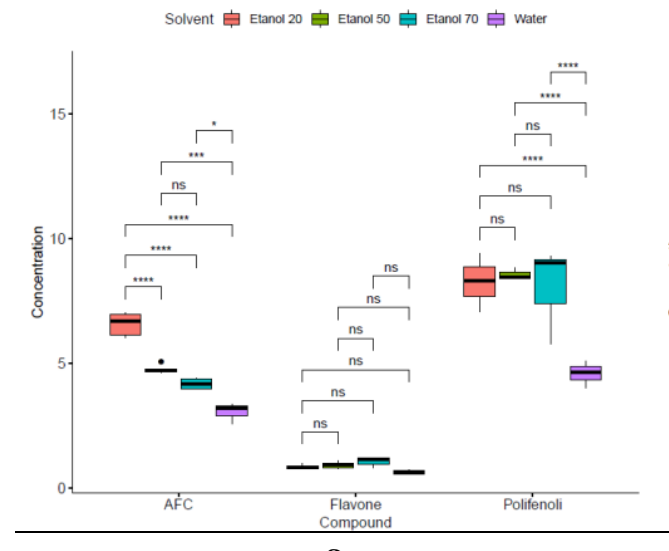

herbal product (expressed as tannic acid equivalents) [26]. Regarding Cichorii herba, there was a statistically significant simple main effect of all active substances $(\mathrm{p}<0.001)$ and solvents $(\mathrm{p}<0.001)$. A different behaviour was observed for $70 \%$ ethanol regarding the PCAs content (Figure 1b).

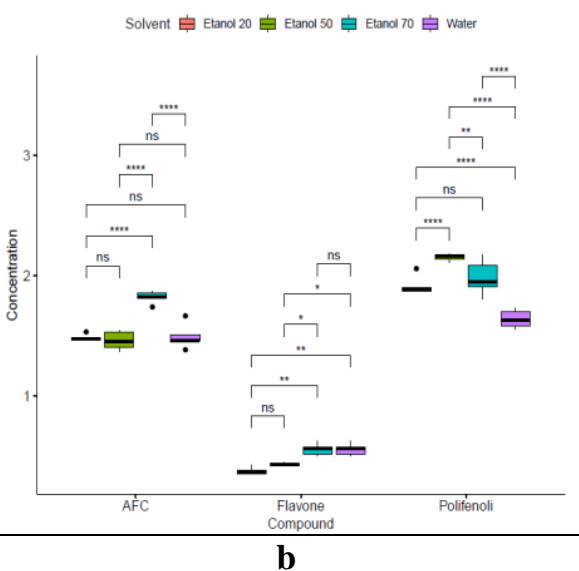

Figure 1.

Statistical analysis (a two-way interaction boxplot) for a - Agrimoniae herba (agrimony aerial parts), $\mathrm{b}-$ Cichorii herba (common cichory aerial parts)

For artichoke leaves (Cynarae folium) we did not find a statistically significant mean difference between PCAs and flavonoids $(\mathrm{p}=0.23)$. Moreover, according to our results, we have not found a statistically significant mean difference between $50 \%$ ethanol and $70 \%$ ethanol $(\mathrm{p}=0.21)$ (Figure $2 \mathrm{a})$. Still, our results regarding the flavonoids $(0.41 \mathrm{~g}$ rutin/100 $\mathrm{g}$ dried herbal product) content (using water as extraction solvent) are much lower compared to other authors, that found $1.99 \mathrm{~g}$ flavonoids/100 $\mathrm{g}$ dried herbal product (expressed as rutin equivalents) [7]. We assume that these differences are the consequence of the herbal product origin, pedoclimatic conditions and extraction methods.
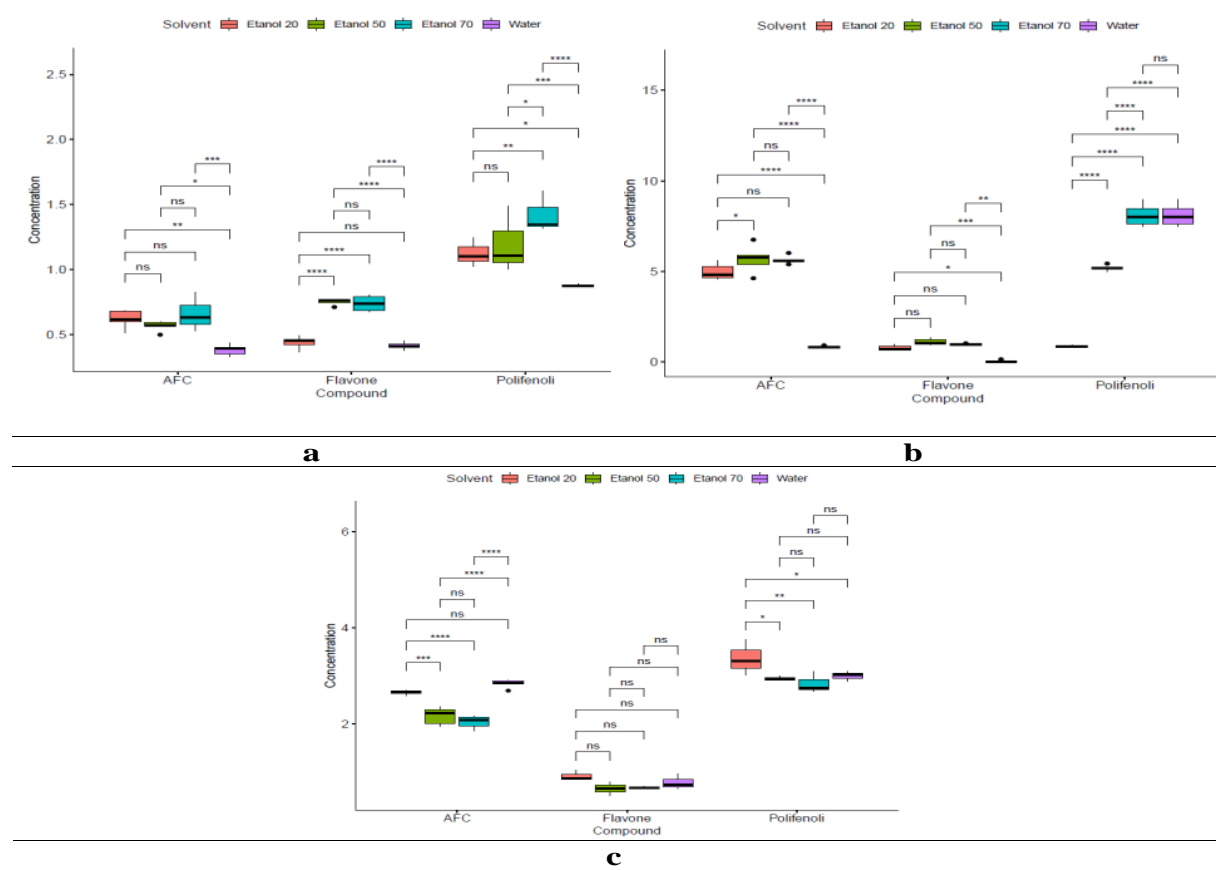

Figure 2.

Statistical analysis (a two- way interaction boxplot) for a - Cynarae folium, b-Rosmarini folium, c - Taraxaci herba 
Our results regarding the total phenolic and flavonoids contents of rosemary leaves (using 50\% ethanol as extraction solvent) (8.10 g tannic acid/100 g dried herbal product and $1.27 \mathrm{~g}$ rutin/100 $\mathrm{g}$ dried herbal product) are similar to our previous published paper (7.88 $\mathrm{g}$ tannic acid/100 $\mathrm{g}$ dried herbal product and 0.90 $\mathrm{g}$ rutin/100 $\mathrm{g}$ dried herbal product respectively) [14]. In case of rosemary leaves, there was a statistically significant simple main effect for all active substances $(\mathrm{p}<0.001)$ and all solvents $(\mathrm{p}<0.001)$. According to our results statistically significant mean differences were found regarding PCAs and flavonoids contents, when using hydroalcoholic solutions compared to water ( $\mathrm{p}<0.001)$. However, regarding the total phenolic content, we did not find statistically significant results, when using $70 \%$ hydroalcoholic and aqueous solutions (Figure 2b).

In case of dandelion aerial parts, there was a statistically significant interaction between active substances and solvent variables $(\mathrm{p}<0.002)$. Significant differences were found regarding the flavonoids and total phenolic contents (except for $20 \%$ ethanol in case of TPC) (Figure 2c). Our results (Table II) have shown that dandelion aerial parts are a rich source of flavonoids and phenolcarboxylic acids, which is in agreement with previous published reports $[10,16,18]$.

Taking into account our results (Table II), 50\% ethanol provided the optimal extraction of phenolic compounds for all analysed herbal products, except for dandelion aerial parts, for which $20 \%$ ethanol was the best extraction solvent.

It is well known that different extraction solvents (methanol, ethanol, mixtures of ethanol/methanol with water, mixture of acetone with water etc.) are used for evaluation of phenolic compounds in herbal products [23].

The efficacy of a certain solvent depends on its ability to dissolve specific phenolic groups; in addition the solvent also influences the plants cell permeability [23]. All-over, flavonoids present a high solubility in alcohol and a higher extraction yield as the content of ethanol in water increases from $50 \%$ ethanol and upward $[6,23]$. Ethanol - in - water solutions (50\%) are more effective than pure water or alcohol for hydroxycinnamic acids extraction [6, 23].

Interesting results were obtained in case of dandelion aerial parts, since $20 \%$ ethanol provided the highest extraction yield of phenolcarboxylic acids and flavones. We assume that these results are probably a consequence of the high amount of polyphenols, mainly found as glycosidic forms (that are more soluble in water) [28].

\section{Conclusions}

All analysed herbal products are a source of flavonoids and phenolcarboxylic acids; still the solvent represents a key factor that greatly influences the phenolic content. According to our results, $50 \%$ ethanol provided the optimal extraction of phenolic compounds for all analysed herbal products, except for dandelion aerial parts (for which $20 \%$ ethanol was the best extraction solvent). Going forwards, our research will look on obtaining freeze-dried extracts rich in phenolic compounds. Furthermore, the extracts will be characterized by means of spectrophotometric/HPLC assays and we shall assess their antioxidant activity and hepatoprotective effects (animal studies).

\section{Acknowledgement}

This work was supported by "Carol Davila” University of Medicine and Pharmacy, Bucharest, Romania, under the $\mathrm{PhD}$ student contract number 28903/02.10.2017.

\section{Conflict of interest}

The authors declare no conflict of interest.

\section{References}

1. Abbas ZK, Saggu S, Sakeran MI, Zidan N, Rehman $\mathrm{H}$, Ansari AA, Phytochemical, antioxidant and mineral composition of hydroalcoholic extract of chicory (Cichorium intybus L.) leaves. Saudi J Biol Sci., 2015; 22(3): 322-326.

2. Abenavoli L, Larussa T, Corea A, Procopio AC, Boccuto L, Dallio M, Luzza F, Dietary Polyphenols and Non-Alcoholic Fatty Liver Disease. Nutrients, 2021; 13(2): 494: 1-10.

3. Abou Seif HS, Physiological changes due to hepatotoxicity and the protective role of some medicinal plants. Beni-suef Univ J Appl Sci., 2016; 5(2): 134-146.

4. Albeanu G, Ghica M, Popentiu-Vladicescu F, On using bootstrap scenario-generation for multi-period stochastic programming applications. Int J Comput Commun Control., 2008; 3: 156-161.

5. Ambade A, Mandrekar P, Oxidative stress and inflammation: essential partners in alcoholic liver disease. Int J Hepatol., 2012; 2012: 853175: 1-9.

6. Assefa, AD, Keum YS, Effect of extraction solvent and various drying methods on polyphenol content and antioxidant activities of yuzu (Citrus junos Sieb ex Tanaka). J Food Meas Charact., 2017; 11(2): 576-585.

7. Ben Salem M, Affes H, Athmouni K, Ksouda K, Dhouibi R, Sahnoun Z, Hammami S, Zeghal KM, Chemical composition, antioxidant and anti-inflammatory activity of Cynara scolymus leaves extracts, and analysis of major bioactive polyphenols by HPLC. Evid Based Compl Alt Med., 2017; 2017: 4951937: 1-14.

8. Cichoż-Lach H, Michalak A, Oxidative stress as a crucial factor in liver diseases. World J Gastroenterol., 2014; 20(25): 8082: 1-11.

9. Ciobanu N, Cojocaru-Toma M, Ciobanu C, Benea A, Evaluation of polyphenolic profile and antioxidant activity of some species cultivated in the Republic of Moldova. Eurasian J Anal Chem., 2018; 13(3) :441- 447.

10. Dobrinas S, Stanciu G, Lupsor S, Total phenolic content and HPLC characterization of some culinary herbs. J Sci Arts, 2017; 2: 321-330.

11. Elufioye TO, Habtemariam S, Hepatoprotective effects of rosmarinic acid: Insight into its mechanisms of 
action. Biomed Pharmacother., 2019; 112: 108600: 1-11.

12. Epure A, Pârvu AE, Vlase L, Benedec D, Hanganu D, Gheldiu AM, Toma VAl, Oniga I, Phytochemical Profile, antioxidant, cardioprotective and nephroprotective activity of Romanian chicory extract. Plants, 2021; 10(1): 64: 1-18.

13. Ezhilarasan D, Oxidative stress is bane in chronic liver diseases: Clinical and experimental perspective. Arab J Gastroenterol., 2018; 19(2): 56-64.

14. Gîrd CE, Nencu I, Popescu ML, Costea T, Duţu LE, Balaci TD, Olaru OT, Chemical, antioxidant and toxicity evaluation of rosemary leaves and its dry extract. Farmacia, 2017; 65(6): 978-983.

15. Ivanov AV, Bartosch $B$, Smirnova OA, Isaguliants MG, Kochetkov SN, HCV and oxidative stress in the liver. Viruses, 2013; 5(2): 439-469.

16. Ivanov IG, Polyphenols content and antioxidant activities of Taraxacum officinale FH Wigg (dandelion) leaves. Int J Pharmacogn Phytochem., 2014; 6(4): 889-893.

17. Li S, Tan HY, Wang N, Cheung F, Hong M, Feng $\mathrm{Y}$, The potential and action mechanism of polyphenols in the treatment of liver diseases. Oxid Med Cell Longev., 2018: 8394818: 1-25.

18. Lis B, Jędrejek D, Stochmal A, Olas B, Assessment of effects of phenolic fractions from leaves and petals of dandelion in selected components of hemostasis. Food Res. Int., 2018; 107: 605-612.

19. Luță EA, Ghica M, Costea T, Gîrd CE, Phytosociological study and its influence on the biosynthesis of active compounds of two medicinal plants Mentha piperita L. and Melissa officinalis L. Farmacia, 2020; 68(5): 919-924.

20. Mair P, Wilcox R, Robust Statistical Methods in R Using the WRS2 Package. Behav Res Methods, 2020; 52: 464-488.

21. Milosevic I, Vujovic A, Barac A, Djelic M, Korac M, Radovanovic Spurnic A, Amedei A, Gut-liver axis, gut microbiota, and its modulation in the management of liver diseases: a review of the literature. Int J Mol Sci., 2019; 20(2): 395: 1-16.

22. Miltonprabu S, Tomczyk M, Skalicka-Woźniak K, Rastrelli L, Daglia M, Nabavi SF, Nabavi SM,
Hepatoprotective effect of quercetin: From chemistry to medicine. Food Chem Toxicol., 2017; 108: 365-374.

23. Oreopoulou A, Tsimogiannis D, Oreopoulou V, Extraction of polyphenols from aromatic and medicinal plants: an overview of the methods and the effect of extraction parameters. In Polyphenols in plants (second edition), Watson RR, Academic Press, 2019; 243-259.

24. R Core Team R, A language and environment for statistical computing. R Foundation for Statistical Computing, Vienna, Austria. URL https://www.Rproject.org/.

25. Saha P, Talukdar AD, Nath R, Sarker SD, Nahar L, Sahu J, Choudhury MD, Role of natural phenolics in hepatoprotection: a mechanistic review and analysis of regulatory network of associated genes. Front Pharmacol., 2019; 10: 509: 1-25.

26. Sahan Y, Gurbuz O, Guldas M, Degirmencioglu N, Begenirbas A, Phenolics, antioxidant capacity and bioaccessibility of chicory varieties (Cichorium spp.) grown in Turkey. Food Chem., 2017; 217: 483-489.

27. Stanciu C, Trifan A, Nonalcoholic steatohepatitis: The mainstay of clinical hepatology. Rev Med Chir., 2019; 123(3): 379-383.

28. Tatiya AV, Tapadiya GG, Kotecha S, Surana SJ, Effects of solvents on total phenolics, antioxidant and antimicrobial properties of Bridelia retusa Spreng. stem bark. Indian J Nat Prod Resour., 2011; 2(4): 442-447.

29. Turker AU, Yildirim AB, Tas I, Ozkan E, Turker H, Evalution of some traditional medicinal plants: phytochemical profile, antibacterial and antioxidant potentials. Rom Biotechnol Lett., 2021; 26(2): 24992510 .

30. Vasincu A, Ababei DC, Rusu RN, Stanciu GD, Chiriac Beschea S, Bild V, Effects of aqueous extract of Veronica kotschyana Sch.Bip. Ex Walp roots on experimental gastric ulcer in mice. Farmacia, 2019; 67(5): 836-843.

31. Videla LA, Rodrigo R, Orellana M, Fernandez V, Tapia G, Quiñones L, Poniachik J, Oxidative stressrelated parameters in the liver of non-alcoholic fatty liver disease patients. Clin Sci., 2004; 106(3): 261-268. 